\title{
Potential impact of urocortin I on sperm count, motility and sex hormone profiles in normal adult rats
}

\author{
Hany A. El kattawy ${ }^{1}$, Mahmoud A. Naga ${ }^{2,3}$, Ahmed Shata ${ }^{3 \star}$ and Mohamed A. Elbaky ${ }^{4}$ \\ ${ }^{1}$ Department of Physiology, Faculty of Medicine, Zagazig University, Zagazig, Egypt. \\ ${ }^{2}$ Department of Clinical Pharmacology and Toxicology, AL-Qunfudh Medical colloge, Umm Al-Qura university, \\ Makka, Saudia Arabia. \\ ${ }^{3}$ Department of Clinical Pharmacology, Mansoura University, Mansoura, Egypt. \\ ${ }^{4}$ Department of Biochemistry, Faculty of Medicine, Minia University, Egypt.
}

Received 22 July 2016: Accepted 19 August 2016

\begin{abstract}
Urocortin I (Ucn I), Ucn II and Ucn III are corticotropin-releasing factor (CRF) - like peptides. Ucn I has a high affinity for $\mathrm{CRF}_{1}$ and $\mathrm{CRF}_{2}$ receptors. The function of Ucn in male reproduction has not yet been elucidated. Ucn I is present in rat testis with lower levels of Ucn II and III mRNA gene expressions. Therefore, it is suggested that Ucn I may play a role in the regulation of male reproductive action. This study is designed to find out the endocrine and reproductive effects of $U \mathrm{cn} I$ in normal adult male rats through investigation of exogenous Ucn I effects on epididymal sperm count, sperm motility, testicular weight and sex hormone profiles. 24 normal adult male albino rats of 175 to $200 \mathrm{gm}$ initial body weight were implemented in this study. Randomly, the rats were subdivided into four equal groups. Group (I): Vehicle-treated group in which control rats received $0.1 \mathrm{~mL}$ of normal saline for $\mathbf{4 2}$ days as Ucn l-treated groups. Rats in group II were divided into three equal subgroups. Group (IIA), (IIB) and (IIC): Ucn Itreated groups in which rats were given daily intraperitoneal injections of rat Ucn I at doses of 5, 10 and $20 \mu \mathrm{g} / \mathrm{kg}$ body weight respectively for 42 days. Rats were weighed. Serum testosterone and levels of Follicle-stimulating hormone (FSH) and Luteinizing hormone (LH) were measured, in addition to epididymal sperm count, sperm motility and testicular weight. Administration of Ucn I in dose dependant manner induced significant reducing effects upon body weight, testes weight, epididymal sperm count, sperm motility and serum testosterone levels of normal adult rats. Ucn I may possibly affect male infertility by induction of a significant decrease in epididymal sperm count, motility and serum testosterone levels that might be due to a direct effect of Ucn I on testicular tissue and the germ cells without direct involvement of hypothalamic-pituitary-gonadal axis.
\end{abstract}

Key words: Urocortin I, epididymal sperm count, sperm motility, testosterone, male rat.

\section{INTRODUCTION}

Urocortin (Ucn) I, II and III and corticotropin releasing hormone ( $\mathrm{CRH})$ are peptide hormones that belong to the

*Corresponding author. E-mail: ahmedmhes@mans.edu.eg.

Author(s) agree that this article remain permanently open access under the terms of the Creative Commons Attribution License 4.0 International License 
corticotropin releasing hormone family of peptides. Ucn I has a high affinity for $\mathrm{CRF}_{1}$ and $\mathrm{CRF}_{2}$ receptors. However, Ucn II and Ucn III show selective $\mathrm{CRF}_{2}$ affinity (Hsu and Hsueh, 2001, Karteris et al., 2004).

Ucn I, II and III have been detected in the central nervous system (Bittencourt et al., 1999) as well as in many peripheral tissues (Kageyama et al., 1999; Lewis et al., 2001, Oki and Sasano, 2004). Ucns have roles in diverse physiologic processes such as regulation of the cardiovascular, gastrointestinal, reproductive, immune functions, body weight, food intake, and behavioral responses to stressors (Rodriguez et al., 1983, Fekete and Zorrilla, 2007).

Ucn I is composed of 40 amino acids with $45 \%$ sequence identity to CRF and $63 \%$ sequence identity to fish urotensin. It was first isolated from rat midbrain (Vaughan et al., 1995; Zhao et al., 1998). The major site of brain Ucn I synthesis is the Edinger-Westphal nucleus (Bittencourt et al., 1999).

The reproductive function of Ucns in male is still unclear. However, both Ucn mRNA and peptide were expressed in mature spermatozoa. Moreover, the expressions of $\mathrm{CRF}_{1}$ and $\mathrm{CRF}_{2}$ receptors in spermatocytes and spermatogonia respectively suggested that Ucns may play a role in the germ cell division, differentiation and spermatogenesis (Tao et al., 2007; Rivier, 2008).

Ucn I gene is located in rat testis with lower detectable levels of Ucn II and III mRNA gene expressions indicating the predominance of Ucn I signals. Ucn I gene expression appeared restricted to interstitial Leydig cells (Lee et al., 2011). Hence, the testis is a main target for Ucn I interactions. The prostate is a main source of local Ucn I. The secreted Ucn in the seminal fluid could activate the myometrial contractility in the female genital tract. So, it is suggested that Ucn I may participate in the physiology of fertilization, pregnancy and parturition (Petraglia et al., 1999; Yutaka and Hironobu., 2004, Lee et al., 2011).

Therefore, this study was designed to find out the endocrinal and reproductive function of $U \mathrm{cn} I$ in male through evaluating the effects of exogenous Ucn I on epididymal sperm count, motility and sex hormone profiles in normal adult rats.

\section{MATERIALS AND METHODS}

24 adult albino male rats weighing 175 - 200 gm were obtained from the animal house of Faculty of Veterinary Medicine- Zagazig University. They were put under well controlled light and temperature conditions before experiments in the physiology animal house in Faculty of Medicine - Zagazig University. Animals were not manipulated except for feeding or cleaning of houses and were allowed to eat and drink ad libitum. Animals were handled with principles for the care and use of research as adopted by the National Institutes of Health and the approval from Animal Ethic Committee of the institution (Egypt). After one week of acclimatization, the rats were randomly and equally divided into four groups. Group (I): Vehicle-treated group in which control rats received $0.1 \mathrm{~mL}$ of normal saline for 42 days. Rats in group II were divided into three equal subgroups. Group (IIA), (IIB) and (IIC): Ucn I-treated groups in which rats were given daily intraperitoneal injections of rat Ucn I at doses of 5,10 and $20 \mu \mathrm{g} / \mathrm{kg}$ body weight respectively for 42 days (Haron et al., 2010). Rat Ucn I (1 mg, powder form, Sigma Chemical Co., St. Louis, USA) was dissolved with $1 \%$ acetate solution and frozen at $-80^{\circ} \mathrm{C}$ until use (Kihara et al., 2001). All injections were performed intraperitoneally in a volume of $0.1 \mathrm{ml} / \mathrm{rat}$.

\section{Samples collection}

$24 \mathrm{~h}$ after the last injection of Ucn I, blood samples were taken from retro-orbital venous plexus. Serum was separated by centrifugation of blood at $3000 \mathrm{rpm}$ for 20 minutes and kept deep frozen at ($20^{\circ} \mathrm{C}$ ). Serum Follicle-stimulating hormone (FSH) and Luteinizing hormone (LH) and testosterone levels were measured. Under mild ether anesthesia, the animals were sacrificed by cervical dislocation. Testes were weighed and epididymis was used for the evaluation of sperm parameters. Repeated freezing and thawing of samples were avoided.

\section{Hormonal assays}

Serum FSH levels were measured using $\mathrm{FSH}$ enzyme immunoassay test kits (BioCheck, CA 94404) according to the method described by Rebar et al. (1982). Both serum LH levels and testosterone levels were measured using LH enzyme immunoassay test kits and testosterone enzyme immunoassay test kits respectively (BioCheck, CA 94404) (Tietz, 1995). All are measured by spectrophotometer (spectronic 3000 Array, Germany) at $450 \mathrm{~nm}$.

\section{Sperm count and motility analysis}

For each rat, the right epididymis was dissected, removed and minced in $2 \mathrm{ml}$ of Hank's buffer salt solution (HBSS) (Sigma-Aldrich Co.-USA) at $37^{\circ} \mathrm{C}$ (Idris et al., 2012). The cauda epididymis sperm was determined using the standard hemocytometer method after 5 min incubation at $37^{\circ} \mathrm{C}$, then the epididymal fluid was drawn up to the 0.5 mark of pipette White Blood Cell (WBC) and the semen diluting fluid (sodium bicarbonate $5 \mathrm{~g}$, formalin $1 \mathrm{ml}$, distilled water $99.0 \mathrm{ml}$ ) was drawn up to '11' mark, and subsequently mixed well. One drop was kept in haemocytometer chamber in humid place for $1 \mathrm{~h}$. Then, under the light microscope, the number of spermatozoa in the appropriate haemocytometer squares was counted according to the formula; sperm count $=$ No. of spermatozoa counted $x$ dilution factor x volume factor/ No. of areas counted (Belsey et al., 1980), the sperm concentration refers to the number of spermatozoa / $\mathrm{ml}$ fluid was gauged.

Using the number of live sperm cells over the total number of sperm cells (either motile which displayed some movement or nonmotile that not move at all), the sperm motility percentage was calculated (Khaki et al., 2009).

\section{Statistical analysis}

The statistical analysis of results was done by using Statistical Package for Social Science (SPSS) program, version 18, for windows XP professional. The biochemical data were expressed as Mean \pm SD. Statistical analysis were performed using one way analysis of variance (ANOVA) followed by post-hoc multiple comparisons (Tukey test). $\mathrm{P}$ value $<0.05$ was considered 
Table 1. Serum LH, FSH, T levels in Ucn I-treated rats and controls after a duration of 42 days.

\begin{tabular}{lccc}
\hline Variable & FSH $(\mu \mathrm{UL} / \mathrm{mL})$ & $\mathbf{L H}(\mu \mathrm{UL} / \mathrm{mL})$ & $\mathbf{T}(\mathbf{n g} / \mathbf{m L})$ \\
\hline Group I (Control rats) & $0.43 \pm 0.04$ & $0.41 \pm 0.07$ & $4.39 \pm 0.79$ \\
Group IIA & $0.40 \pm 0.03$ & $0.39 \pm 0.05$ & $3.5 \pm 0.47$ \\
Group IIB & $0.38 \pm 0.04$ & $0.40 \pm 0.04$ & $2.7 \pm 0.34^{\mathrm{p} 1, \mathrm{p} 2}$ \\
Group IIC & $0.37 \pm 0.04$ & $0.37 \pm 0.073$ & $1.87 \pm 0.41^{\mathrm{p} 1, \mathrm{p} 2}$ \\
\hline
\end{tabular}

p1 = significant difference when compared with negative control group, p2 significant when compared with group Ila, p3 when compared with group IIb

Table 2. Epididymal sperm count, motility and testis weight in Ucn I-treated rats and controls after a duration of 42 days.

\begin{tabular}{lcccc}
\hline Variable & $\begin{array}{c}\text { Epididymal sperm } \\
\text { count (millions/mI) }\end{array}$ & $\begin{array}{c}\text { Total sperm } \\
\text { motility (\%) }\end{array}$ & $\begin{array}{c}\text { Progressive } \\
\text { motility (\%) }\end{array}$ & Testis weight (g) \\
\hline Group I (Control rats) & $53.1 \pm 5.9$ & $85.9 \pm 9.8$ & $78.9 \pm 8.86$ & $1.84 \pm 0.3$ \\
Group IIA & $43.7 \pm 5.5^{\mathrm{p} 1}$ & $70.3 \pm 7.4^{\mathrm{p} 1}$ & $61.72 \pm 8.1^{\mathrm{p} 1}$ & $1.48 \pm 0.17^{\mathrm{p} 1}$ \\
Group IIB & $40.7 \pm 5.5^{\mathrm{p} 1}$ & $67.1 \pm 10.6^{\mathrm{p} 1}$ & $59.4 \pm 11.1^{\mathrm{p} 1}$ & $1.17 \pm 0.16^{\mathrm{p} 1}$ \\
Group IIC & $35.2 \pm 6.1^{\mathrm{p} 1}$ & $60.1 \pm 9.2^{\mathrm{p} 1}$ & $56.31 \pm 11.35^{\mathrm{p} 1}$ & $0.87 \pm 0.13^{\mathrm{p} 1}$ \\
\hline
\end{tabular}

p1 = significant difference when compared with negative control group, p2 significant when compared with group Ila, p3 when compared with group Ilb

Total Motility = Progressive Motility + Non-progressive Motility; Progressive motility: sperms moving actively, either linearly or in large circle regardless of speed; Non-progressive motility: all other motility patterns with an absence of progression (i.e. swimming in a small circle or when only a flagellar beat can be observed); Immotile sperms: no movement.

statistically significant at confidence interval $95 \%$.

\section{RESULTS}

\section{Hormone assays}

Table 1 shows the effects of Ucn I on hormones in the studied groups. Following treatment with different doses of Ucn I, the results showed no significant differences were evident in serum FSH and $\mathrm{LH}$ levels between rats given Ucn I and their age-matched controls ( $p 1>0.05)$. However, $T$ was significantly lower in rats treated with 10 and $20 \mu \mathrm{g} \mathrm{/} \mathrm{kg}$ (p2<0.04, p2<0.001 respectively) compared to those treated by $5 \mu \mathrm{g} / \mathrm{kg}$ of Ucn I in same group and their age-matched controls ( $p 1<0.001, p 1$ $<0.001$ respectively). As presented in Table 2 Epididymal sperm count, motility and testis weight were significantly lower in rats given Ucn $I$ at doses of $5 \mu \mathrm{g}(\mathrm{p} 1<0.05$, $\mathrm{p} 1<0.05, \mathrm{p} 1<0.04$ respectively), $10 \mu \mathrm{g} / \mathrm{kg}$ body weight (p1<0.006, p1<0.01, p1<0.001 respectively) and $20 \mu \mathrm{g} /$ $\mathrm{kg}$ body weight $(\mathrm{p} 1<0.001, \mathrm{p} 1<0.001, \mathrm{p} 1<0.001$ respectively) compared to their age-matched controls.

\section{DISCUSSION}

Male infertility is a major health problem that represents approximately $30 \%$ of all infertilities (Carlsen et al., 1992; Isidori et al., 2006). While stress activates the hypothalamic-pituitary-adrenal (HPA) axis, it suppresses the hypothalamic-pituitary-gonadal (HPG) axis (Kageyama, 2013, Bhongade et al., 2015). Stress profoundly inhibits the reproductive function by suppressing the pulsatile release of hypothalamic gonadotropin-releasing hormone $(\mathrm{GnRH})$ and consequently luteinizing hormone (LH), at least in part via the corticotrophin-releasing factor (CRF) system as well as through the GABAergic system (Lin et al., 2012, Bhongade et al., 2015).

The release of CRF in response to various stressors suppresses of the HPG axis, especially the GnRH pulse generator in the hypothalamus, and also decreases $\mathrm{GnRH}$ mRNA levels via the $\mathrm{CRF}_{1}$ receptors (Kagayama, 2013). Locally, CRF was found to exert an inhibitory effect on Leydig cell activity in rat testes (Dufau et al., 1993). However, Urocortin I (Ucn I), rather than CRF, is located in rat Leydig cells (Hardy et al., 2005).

Ucn I is an endogenously secreted corticotrophinreleasing factor (CRF)-related peptide. Ucn I is a 40amino acid peptide that shares $45 \%$ homology with CRF (Vaughan et al., 1995; Zhao et al., 1998). In addition, Ucn I exerts its biological activity through $\mathrm{CRF}_{1}$ and $\mathrm{CRF}_{2}$ receptors and binds to both types with high affinity (Hsu and Hsueh, 2001). Neurons in the centrally projecting Edinger-Westphal nucleus are the main site of Ucn I synthesis in the mammalian brain, and are assumed to play a role in the stress response. Acute and chronic stress resulted in an increase in Ucn I content of the 
Edinger-Westphal nucleus (Derks et al., 2012).

Both CRF and Ucn I contribute to stress responses, cardiovascular and gonadal functions via $G$ proteincoupled seven transmembrane receptors (Vale et al., 1997; Kageyama et al., 1999a; Suda et al., 2004). It is well known that anxiety has a detrimental effect on fertility (Demyttenaere et al., 1988). Ucn I was found to elicit an increase in anxiogenic behavior and potentiate the anxiogenic action of ghrelin as well (Currie et al., 2014).

Therefore, this study is implemented to find out the probable endocrine and reproductive actions of Ucn I in adult male rats via investigation of the effects of exogenous Ucn I on epididymal sperm count, motility, testicular weight and sex hormone profiles. The study of the current hypothesis is that CRF-related peptides act within the gonads, rather than in the periphery, and that their influence on Leydig cells activity is at least partly due to rapid decreases in levels of the steroidogenic enzymes (Herman and Rivier, 2006).

In the present study, Ucn I administration for 42 days significantly decreased the testis weight, epididymal sperm count and motility. These findings are collaborated by the findings of Tao et al. (2007) who hold that Ucn I significantly inhibited the sperm motility and ascrosome reaction in a concentration-dependent manner. It inhibited T-type calcium channels in mouse spermatogenic cells, sperm motility and progesteroneevoked sperm acrosome reaction, indicating that inhibition of $\mathrm{Ca}^{2+}$ channels may be a mechanism for the inhibitory effects of Ucn I on male reproductive functions. Ucn I might decrease $\mathrm{Ca}^{2+}$ via inhibiting T-type calcium channels directly in male reproductive cells, instead of binding to its receptors firstly (Tao et al., 2005).

The duration of treatment was documented by Haron et al. (2010). As the germ cells are arranged in specific cell associations, called the stages of the cycle of the seminiferous epithelium. For the rat, the fourteen different stages of each cycle of the seminiferous epithelium last approximately 13 days. The germ cell traverses the different stages of the cycle four times for its complete development, which takes all together 52 days (Clermont, 1972; Karl et al., 1991).

Intraperitoneal administration of Ucn I in the present study significantly decreased the serum testosterone levels. These results are in consistent with findings of Rivier (2008) who reported that intratesticular administration of CRF and Ucn I significantly inhibited the testosterone response to LH-like molecules such as human chorionic gonadotropin (hCG). Ucn I was more effective than CRF in inhibiting Leydig cell responsiveness.

This study further suggested that the intraperitoneal Ucn I administration may be an effective route in inhibition of the release of testosterone from Leydig cells. Ucn I may penetrate the testes after its intraperitoneal injection and acted via a testicularly mediated site of action. Blood-borne compounds readily penetrate the intensely vascularized testes.

In the present study, no significant differences were evident in serum FSH and $\mathrm{LH}$ levels between Ucn Itreated rats and their age-matched controls. These results are in agreement with findings of Rivier (2008) who reported that blockade of endogenous LH before Ucn I injection did not alter the inhibitory effect of this peptide regardless of whether it was administered into the general circulation or into the testes.

In addition, it was suggested that the inhibitory influence of CRF-related peptides on testosterone response to gonadotropins is primarily exerted through $\mathrm{CRF}_{1}$ receptor activation (Li et al., 2005). It is Ucn I, rather than CRF, that is located in rat Leydig cells (Hardy et al., 2005). However, stress-induced suppression of LH pulses was mediated by $\mathrm{CRF}_{2}$ receptors probably through pituitary Ucn II (Nemoto et al., 2010).

\section{Conclusion}

The results of this study indicate that Ucn I administration significantly reduces testis weight, sperm count, motility and serum testosterone level which does not seem to directly involve the hypothalamic-pituitary-gonadal axis but might be due to a direct effect of Ucn I on testicular tissue and the germ cells.

\section{Conflict of Interests}

The authors have not declared any conflict of interests.

\section{REFERENCES}

Belsey MA, Moshissi KS, Eliasson R, Paulsen CA, Callegos AJ, Prasad MR (1980). Laboratory manual for the examination of human semen and semen cervical mucus interaction. Press concern.

Bhongade MB, Prasad S, Jiloha RC, Ray PC, Mohapatra S, Koner BC (2015). Effect of psychological stress on fertility hormones and seminal quality in male partners of infertile couples. Andrologia 47(3):336-342.

Bittencourt JC, Vaughan J, Arias C, Rissman RA, Vale WW, Sawchenko PE (1999). Urocortin expression in rat brain: evidence against a pervasive relationship of urocortin-containing projections with targets bearing type 2 CRF receptors. J. Comp. Neurol. 415:285312

Carlsen E, Giwercman A, Keiding N, Skakkebaek NE (1992). Evidence for decreasing quality of semen during past 50 years. BMJ 305:609613.

Clermont $Y$ (1972). Kinetics of spermatogenesis in mammals: seminiferous epithelium cycle and spermatogonial renewal. Physiol. Rev. 52:198-235.

Currie PJ, Schuette LM, Wauson SE, Voss WN, Angeles MJ (2014). Activation of urocortin 1 and ghrelin signaling in the basolateral amygdala induces anxiogenesis. Neuroreport 25(1):60-64.

Demyttenaere K, Nijs P, Steeno O, Koninckx PR, Everse-Kiebooms G (1988). Anxiety and conception rates in donor in semi nation. J. Psychosom. Obstet Gynaecol. 8:175-181.

Derks NM, Pintér O, Zuure W, Ledent C, Watanabe M, Molnár CS, Wei Y, Roubos EW, Wu S, Hrabovszky E, Zelena D, Kozicz T (2012). Cannabinoid modulation of midbrain urocortin 1 neurones during 
acute and chronic stress. J. Neuroendocrinol. 24(11):1447-1461.

Dufau ML, Tinajero JC, Fabbri A (1993). Corticotropin-releasing factor: an antireproductive hormone of the testis. FASEB J 7:299-307.

Fekete ÉM, Zorrilla EP (2007). Physiology, pharmacology and therapeutic relevance of urocortins in mammals: Ancient CRF paralogs. Front. Neuroendocrinol. 28:1-27.

Hardy MP, Gao HB, Dong Q, Ge R, Wang Q, Chai WR, Feng X, Sottas $C$ (2005). Stress hormone and male reproductive function. Cell Tissue Res. 322:147-153.

Haron MN, D'Souza UJ, Jaafar H, Zakaria R, Singh HJ (2010). Exogenous leptin administration decreases sperm count and increases the fraction of abnormal sperm in adult rats. Fertil Steril. 93(1):322-324.

Herman M, Rivier C (2006). Activation of a neural brain-testicular pathway rapidly lowers Leydig cell levels of the steroidogenic acute regulatory protein and the peripheral-type benzodiazepine receptor while increasing levels of neuronal nitric oxide synthase. Endocrinology 147(1):624-633.

Hsu SY, Hsueh AJ (2001). Human stresscopin and stresscopin-related peptide are selective ligands for the type 2 corticotropin releasing hormone receptor. Nat. Med. 7:605-611.

Idris $\mathrm{MH}$, Budin SB, Osman M, Mohamed J (2012). Protective role of hibiscus sabdariffa calyx extract against streptozotocin induced sperm damage in diabetic rats. EXCLI J. 11:659-669.

Isidori AM, Pozza C, Gianfrilli D, Isidori A (2006). Medical treatment to improve sperm quality. J. Reprod. Biomed. 12:704-714.

Kageyama K (2013). Regulation of gonadotropins by corticotropinreleasing factor and urocortin. Front. Endocrinol. 4:12.

Kageyama K, Bradbury MJ, Zhao L, Blount AL, Vale WW (1999a). Urocortin messenger ribonucleic acid: tissue distribution in the rat and regulation in thymus by lipopolysaccharide and glucocorticoids. Endocrinology 140(12):5651-5658.

Karl PI, Katz R, Daum F, Fisher SE (1991) Mercaptopurine and spermatogenesis in the young rat. Dig. Dis. Sci. 36:1569-1573.

Karteris E, Hillhouse EW, Grammatopoulos D (2004). Urocortin II is expressed in human pregnant myometrial cells and regulates myosin light chain phosphorylation: potential role of the type-2 corticotropinreleasing hormone receptor in the control of myometrial contractility. Endocrinology 145:890-900.

Khaki A, Nouri M, Fathiazad F, Ahmadi-Ashtiani HR, Rastgar $H$, Rezazadeh. (2009). Protective Effects of Quercetin on Spermatogenesis in Streptozotocin induced Diabetic Rat. J. Med. Plant 9(35):143-150.

Kihara N, Fujimura M, Yamamoto I, Itoh E, Inui A, Fujimiya M (2001). Effects of central and peripheral urocortin on fed and fasted gastroduodenal motor activity in conscious rats. Am. J. Physiol. Gastrointest. Liver Physiol. 280:G406-G419.

Lee S, Braden B, Kang SS, Rivier C (2011). Urocortins are Present in the Rat Testis. Neuropeptides 45(2):131-137.

Lewis K, Li C, Perrin MH, Blount A, Kunitake K, Donaldson C, Vaughan J, Reyes TM, Gulyas J, Fischer W, Bilezikjian L, Rivier J, Sawchenko PE, Vale WW (2001). Identification of urocortin III, an additional member of the corticotropin-releasing factor (CRF) family with high affinity for the CRF2 receptor. Proc. Natl. Acad. Sci USA 98:75707575.

Li XF, Bowe JE, Lightman SL, O'Byrne KT (2005). Role of corticotropinreleasing factor receptor-2 in stress-induced suppression of pulsatile luteinizing hormone secretion in the rat. Endocrinology 146(1):318322.

Lin YS, Li XF, Shao B, Hu MH, Goundry AL, Jeyaram A, Lightman SL, O'Byrne KT (2012). The Role of GABAergic Signalling in Stress-Induced Suppression of Gonadotrophin-Releasing Hormone Pulse Generator Frequency in Female Rats. J. Neuroendocrinol. 24(3):477-488.

Nemoto T, Iwasaki-Sekino A, Yamauchi N, Shibasaki T (2010). Role of urocortin 2 secreted by the pituitary in the stress-induced suppression of luteinizing hormone secretion in rats. Am J Physiol Endocrinol Metab. 299(4):E567-E575.

Oki Y, Sasano H (2004). Localization and physiological roles of urocortin. Peptides 25:1745-1749.

Petraglia F, Florio P, Benedetto C, Marozio L, Di Blasio AM, Ticconi C
(1999). Urocortin stimulates placental adrenocorticotropin and prostaglandin release and myometrial contractility in vitro. J. Clin. Endocrinol. Metab. 84:1420-1423.

Rebar RW, Morandini IC, Petze JE, Erickson GF (1982). Hormonal basis of reproductive defects in athymic mice: reduced gonadotropins and testosterone in males. Biol. Reprod. 5:1267-1276.

Rivier CL (2008). Urocortin 1 Inhibits Rat Leydig Cell Function. Endocrinology 149(12):6425-6432.

Rodriguez B, Bermudez L, Poncede Leon E, Castro L (1983). Presented at the third world congress of behavior therapy. Washington DC; The relationship between infertility and anxiety: some preliminary findings. December 8-11.

Suda T, Kageyama K, Sakihara S, Nigawara T (2004). Review Physiological roles of urocortins, human homologues of fish urotensin I, and their receptors. Peptides 25(10):1689-701.

Tao J, Min Lin, , Jiahao Sha, Gregory Tan, Tuck Wah Soong, Shengnan Li (2007). Separate Locations of Urocortin and its Receptors in Mouse Testis: Function in Male Reproduction and the Relevant Mechanisms. Cell. Physiol. Cell Physiol. Biochem. 19:303-312.

Tao J, Wu Y, Chen J, Zhu H, Li S (2005). Effects of urocortin on T-type calcium currents in mouse spermatogenic cells. Biochem. Biophys. Res Commun. 329:743-748.

Tietz NW (1995). Clinical Guide to Laboratory Tests, 3rd Ed., W.B. Saunders Company, Philadelphia pp. 509-580.

Vale W, Vaughan J, Perrin MH (1997). Corticotropin-releasing factor (CRF) family ligands and their receptors. Endocrinologist 7:3S-9S.

Vaughan J, Donaldson C, Bittencourt J, Perrin MH, Lewis K, Sutton S, Chan R, Turnbull AV, Lovejoy D, Rivier C, Rivier J (1995). Urocortin, a mammalian neuropeptide related to fish urotensin I and to corticotropin-releasing factor. Nature 378(6554):287-292.

Yutaka O, Hironobu S (2004). Localization and physiological roles of urocortin. Peptides 25:1745-1749.

Zhao L, Donaldson CJ, Smith GW, Vale WW (1998). The structures of the mouse and human urocortin genes (Ucn and UCN).Genomics 50:23-33. 